\title{
Molecular Cloning of Pyruvate Formate Lyase Gene of Staphylococcus aureus Associated with Bovine Mastitis
}

\author{
Varra Manasa ${ }^{1 *}$, T. Venkata Sai Kumar², T. Prasada Rao², \\ K. Aswani Kumar ${ }^{3}$, J. Thanislass ${ }^{4}$ and V. Girish Kumar ${ }^{5}$ \\ ${ }^{1}$ Department of VBC, Veterinary College, Hebbal, KVAFSU, India \\ ${ }^{2}$ Department of $V B C, C . V . S c, P D T R, S V V U$, India \\ ${ }^{3}$ Department of VBC, N.T.R C.V.Sc, Gannavaram, SVVU, India \\ ${ }^{4}$ Department of $V B C$, RIVER, Puducherry, India \\ ${ }^{5}$ Department of VBC, Veterinary College, Hebbal, KVAFSU, India
}

*Corresponding author

\section{A B S T R A C T}

\begin{tabular}{l}
\hline Key w or d s \\
$\begin{array}{l}\text { Staphylococcus } \\
\text { aureus, Bovine } \\
\text { mastitis, Pyruvate } \\
\text { formate lyase gene } \\
\text { (PFL gene), } \\
\text { Cloning, } \\
\text { Immunogenic } \\
\text { protein }\end{array}$ \\
\hline $\begin{array}{l}\text { Article Info } \\
\text { Accepted: } \\
\text { 07 November } 2020 \\
\text { Available Online: } \\
\text { 10 December } 2020\end{array}$ \\
\hline
\end{tabular}

\section{Keywords}

Staphylococcus aureus, Bovine formate lyase gene (PFL gene), Cloning, nogenic

Article Info

Accepted: Available Online:
Puruvate formate lyase (PFL) of Staphylococcus aureus is an important protein which gets expressed mainly as an adaptive response for their survival in the host mammary tissue by way of producing biofilm. This adaptive mechanism of $S$. aureus mainly contributes to sub-clinical, chronic bovine mastitis which often becomes challenging to treat with conventional antibiotics and thereby the prevention of further spread of infection in the herd becomes difficult. The present preliminary study is an attempt to clone and characterize 609 bp antigenic site of pyruvate formate lyase gene of $S$. aureus associated with bovine mastitis. The partial PFL gene cloned using TA cloning vector showed 9899\% identity with the reference sequence available in the Genbank (MK695632). The cloned insert with overhangs released by restriction enzyme digestion can be used to obtain the antigenic protein by using pET 32a+ expression vector system. The antibodies to pyruvate formate lyase were obtained in the serum of cows associated with $S$. aureus bovine mastitis which was as an important finding in Serological Proteome Analysis (SERPA). Therefore the protein expressed from the cloned partial PFL gene can be used for the development of immunoassay kit for early diagnosis and also as a vaccine candidate for the control and prevention of $S$. aureus associated bovine mastitis.

\section{Introduction}

S. aureus is one of the main causative agents of bovine mastitis, the most economically important disease of dairy ruminants (Tesfaye et al., 2010; Banerjee et al., 2019). Among all the pathogens causing mastitis, $S$. aureus is of important concern because of its ability to cause chronic disease. Existence of Small Colony Variants (SCVs) of S. aureus and Methicillin Resistant Staphylococcus aureus (MRSA) among the $S$. aureus isolates of bovine mastitis is an increasing concern because of its zoonotic importance (Gopal and Divya, 2017; Gravel and Malouin, 2018; Atalla et al., 2011). S. aureus also exhibits 
resistance to antiseptics and disinfectants, such as quaternary ammonium compounds, which may aid its survival in the hospital environment. Biofilm associated S. aureus were found to exhibit innate resistance to antibiotics, disinfectants and clearance by host defenses (Aslantas and Demir, 2016).

S. aureus remains as one of the major disease causing organisms of contagious bovine mastitis due to its unique ability to escape the innate immune response such as phagocytic, complement or antimicrobial peptide (AMP)mediated killing assisting its survival in blood and other tissues during chronic infections (Hensen et al., 2000; Gresham et al., 2000; Barrio et al., 2006; Zecconi et al., 2006; Gunther et al., 2017). Many vaccines are commercially available against $S$. aureus associated with bovine mastitis, but are failing to give protective immunity except few trials which are successful at the herd level mostly (Annemuller et al., 1999; Fitzgerald et al., 1997; Saei et al., 2009).

Multiple factors account for the lack of protection, like the selection of vaccine targets, high diversity among mastitisprovoking strains, variation in immune response between animals and a failure to elicit an immune response that is required for protection against this complex intramammary pathogen (Gravel and Malouin., 2018). Therefore, this demands an urgent need for the development of alternative vaccines that either prevent infection or facilitate clearance of the bacteria from the mammary gland very shortly after intra mammary infection. This can not only help to prevent $S$. aureus bovine mastitis, but also to eliminate the possibility of chronic infection that can serve as a reservoir of infection to the herd-mates (Rainard et al., 2018).

The specific and general defense mechanisms of $S$. aureus are based on the sophisticated pathways of signal transduction, which subsequently trigger changes in gene expression (Falko et al., 2008). Tissue specific (udder and / or its secretions) gene expression studies of $S$. aureus may help to identify antimicrobials or drug targets that can effectively treat the $S$. aureus to overcome the existing problem of multidrug resistance. The expression of $P F L$ gene was identified in the clinical isolates of $S$. aureus associated with bovine mastitis with the help of serological proteome analysis (SERPA) (Anitha et al., 2014). Puruvate formate lyase is an important protein involved in anaerobic glucose metabolism (Leibig et al., 2011).

The expression of PFL gene in S. aureus associated with bovine mastitis has been found to be mainly as an adaptive response for the survival of the organism through the formation of biofilm (Manasa et al., 2014). With this background, the present work was designed to clone and express this PFL gene of $S$. aureus associated with bovine mastitis in the process of either making a protein for use as vaccine or developing an immune assay kit for early diagnosis. The protein once obtained in bulk can also be used in studies for the identification of alternate and effective drugs that can inhibit this crucial enzyme necessary for survival of $S$. aureus in the udder tissue.

\section{Materials and Methods}

\section{Bacterial isolate}

The field strain of Staphylococcus sp. was initially isolated on Mueller Hinton agar with $7 \%$ sodium chloride which was then streaked on to Baird Parker agar supplemented with egg yolk emulsion and potassium tellurite solution (Hi media) for the identification of $S$. aureus. The field strains of $S$. aureus were then further confirmed by PCR for $S$. aureus by the amplification of nuc gene (Brakstad et al., 1992; Manasa et al., 2019). 


\section{Primer designing}

The gene locus tag SACOL204 with the GI no. 57285406 was used for the designing of primers for the amplification of PFL gene of S.aureus. The position of the nucleotide sequence is from 239821- 242070. Artificial neural network based B-cell epitope prediction server (ABC pred server) was used to predict the antigenic sites in the full length gene of pflB. Using DNASTAR lasergenev6 software package and oligoanalyser, primers were designed for the amplification of $609 \mathrm{bp}$ PCR product which contain the predictive antigenic sites. Restriction enzyme (RE) site for Bam HI was introduced while designing the reverse primer and RE site for Nco I was introduced while designing the forward primer (Table 1). These RE sites were introduced for the cloning of partial PFL gene using the TA cloning kit with one shot $\mathrm{INV} \alpha \mathrm{F}$ chemically competent $E$. coli from Invitrogen (K2000-01). The RE sites also serve an advantage of digesting the recombinant plasmids with the REs for the directional cloning and expression of partial PFL gene product which is predicted to be antigenic. The TA cloning vector used in the study and pET 32a+ selected for expression of PFL protein product are being represented in Fig. $1 \mathrm{a}$ and $1 \mathrm{~b}$. The primer specificity was checked by using primer-BLAST. The specific set of primers used in the cloning experiment was synthesized from Eurofins Genomics India Pvt. Ltd., Bangalore.

\section{Determining the specificity of primers designed}

The specificity of the primers designed was determined by performing PCR using the designed primers wherein the DNA isolated from field strains of $S$. aureus was used as the template. A $20 \mu \mathrm{l}$ reaction mixture was prepared which contained 5.0 $\mu$ l of DNA template $(0.2 \mu \mathrm{g} / \mu \mathrm{l}), 1.0 \mu \mathrm{l}$ of forward primer
$(10 \mathrm{pmol} / \mu \mathrm{l}), \quad 1.0 \quad \mu \mathrm{l}$ of reverse primer $(10 \mathrm{pmol} / \mu \mathrm{l}), 10.0 \mu \mathrm{l}$ of Dream Taq green PCR master mix (2X) form Thermo scientific and $3.0 \mu \mathrm{l}$ of nuclease free water. The amplification conditions standardized were as follows: an initial denaturation of $94^{\circ} \mathrm{C}$ for 5 minutes; 30 cycles of $94^{\circ} \mathrm{C}$ for $30 \mathrm{sec}, 60^{\circ} \mathrm{C}$ for $40 \mathrm{sec}$ and $72^{\circ} \mathrm{C}$ for $40 \mathrm{sec}$ and a final extension step at $72^{\circ} \mathrm{C}$ for $5 \mathrm{~min}$. The amplified gene product was confirmed for the expected amplicon size by agarose gel electrophoresis. The PFL gene product so obtained was then purified from the gel by using Thermo scientific Gene JET gel extraction kit. The purified PFL PCR product was then custom sequenced by Eurofins genomics India Pvt. Ltd, Bangalore. The sequence obtained was subjected for sequence analysis using BLAST. With the help of BLAST score and e-value, the specificity of the sequence was ascertained.

\section{Cloning of partial pflB gene in TA cloning vector}

Fresh PCR products of partial PFL gene (609bp) obtained from field isolates of $S$. aureus associated with bovine mastitis were ligated with the TA cloning vector by using manufacturer's protocol with slight modifications. Pfu DNA Polymerase, recombinant (Thermo Scientific \#EP0501) was used for obtaining the amplicons for the cloning experiment by setting up PCR reaction of $50 \mu \mathrm{l}$ with manufacturers protocol with slight modifications using the same primers designed for cloning. Cloning of the partial PFL gene into the TA cloning vector involved the three basic steps: Ligation, transformation and plating which are as follows.

Ligation: A $10 \mu 1$ reaction was set up for ligation of amplified partial $p f l B$ gene with the above described TA cloning vector using $1 \mu \mathrm{l}$ each of PCR product and T4 DNA ligase 
enzyme, $2 \mu 1$ each of $5 \mathrm{X}$ T4 DNA ligase reaction buffer and TA cloning vector. The final volume was made to $10 \mu 1$ with nuclease free water. This ligation reaction was incubated at $37^{\circ} \mathrm{C}$ for $1 \mathrm{hr}$ and stored at $4{ }^{\circ} \mathrm{C}$ overnight.

Transformation: Transformation was done by following the manufacturer's protocol with slight modifications and by using the INV $\alpha \mathrm{F}$ competent $E$. coli cells provided in the kit and also by using $\mathrm{DH} 5 \alpha$ cells. Water bath was equilibrated to $42^{\circ} \mathrm{C}$ and SOC medium was brought to room temperature. $\mathrm{X}$-gal $(40 \mathrm{mg} / \mathrm{ml})$ was added to the prepared LB agar plates with ampicillin $(0.1 \mathrm{~g} / \mathrm{ml})$. The competent cells were thawed on ice for transformation. The ligation reaction was also kept on ice. $2 \mu l$ each of ligation reaction was directly added to the vials of competent cells. The vials were incubated on ice for $30 \mathrm{~min}$. Transformation was aided by subjecting the cells to heat shock at $42^{\circ} \mathrm{C}$ for $30 \mathrm{sec}$. The vials were immediately transferred to ice. 250 $\mu \mathrm{l}$ of SOC medium was added to each vial. The vials were then incubated in a horizontal shaker at $37^{\circ} \mathrm{c}$ for $1 \mathrm{hr}$ at $225 \mathrm{rpm}$.

Plating: $50 \mu \mathrm{l}$ of transformation mix was then plated on to the LB agar plates containing ampicillin. The plates were then incubated overnight at $37^{\circ} \mathrm{C}$ for obtaining the recombinant clones. The same procedure mentioned above was used for transformation of ligation reaction into $\mathrm{DH} 5 \alpha$ cells (with slight modifications) excepting that there was addition of IPTG $(100 \mathrm{mM})$ to the LB agar media at the final concentration of $1 \mathrm{mM}$.

\section{Screening of recombinant clones}

The identification of the recombinant clones was done by employing all the possible methods which included the blue white screening, colony PCR, plasmid PCR, sequence analysis of insert in the recombinant (r) clones and rrestriction enzyme (RE) analysis of $r$ clones which are briefly described as follows:

Blue-white screening: The recombinant plasmids were screened by the visual identification of white colonies on the LB agar plates upon incubation with the transformed cells. White colonies actually represent the insertion of gene of insert into the vector and thereby the disruption of the lac $Z$ coding for the $\beta$ galactosidase whose substrate is $\mathrm{X}$-gal.

Colony PCR: A $25 \mu 1$ reaction was set up with $12.5 \mu \mathrm{l}$ of Dream taq green PCR master mix (Thermo Scientific), $1 \mu \mathrm{l}$ of forward primer, $1 \mu l$ of reverse primer, a portion of transformed colony (white) as template and $10.5 \mu \mathrm{l}$ of nuclease free water. Amplification was carried out by using PCR conditions standardized above for the amplification of partial pflB gene of $S$. aureus.

Plasmid PCR: In order to perform the plasmid PCR, recombinant DNA was isolated from the transformed cells (white colonies) after inoculating into $1.5 \mathrm{ml}$ luria broth with ampicillin and incubation at $37^{\circ} \mathrm{C}$ overnight. The isolation of plasmid was then carried out by alkaline lysis method with minor modifications (Behle., 2017). The plasmid pellet obtained was then reconstituted with 20-30 $\mu 1$ of TE buffer. Plasmid PCR was then performed using the isolated recombinant DNA as a template for PCR.

Sequence analysis of insert in the recombinant (r) clones: For the further confirmation of the sequence specificity of partial $p f l B$ gene insert in the recombinant plasmid, the plasmids were gel extracted and purified which were then custom sequenced by Eurofins Genomics India Pvt. Ltd., Bangalore. The sequences obtained were then subjected for sequence analysis using 
BLAST. With the help of BLAST score and e-value, the specificity of the insert sequence in the TA cloning vector was ascertained.

\section{Restriction enzyme analysis of $r$ clones}

The insert was then released from the recombinant plasmid by digesting with Nco I (Thermoscientific) using manufacturers' protocol with slight modification. The size of the Nco I digested recombinant plasmid (pCR2.1) in comparison with the $1 \mathrm{~Kb}$ plus ladder was ascertained. The band corresponding to $3000 \mathrm{~Kb}$ was gel extracted and purified, the resultant purified product was then subjected for Bam HI (Thermo Scientific) digestion using manufacturers' protocol with slight modification. The insert obtained as a result of sequential Nco I and Bam HI digestion was then gel purified and stored at $-80^{\circ} \mathrm{C}$ for cloning and expressing the partial pflB gene in the directional expression vector.

\section{Results and Discussion}

The S. aureus field strain isolated on Baird Parker agar characterized by the appearance of black colonies surrounded by a clear zone is depicted in Fig. 2. Further confirmation of $S$. aureus by PCR resulted in the amplification of 270bp nuc gene specific to $S$. aureus. The specificity of primers designed for the amplification of partial PFL gene of $S$. aureus intended for initial cloning in the TA cloning vector and further expression in pET32a+ vector system resulted in the specific amplification of $609 \mathrm{bp}$ PCR product (Fig. 3). The sequenced PCR product also revealed $99-100 \%$ identity with the $S$. aureus PFL gene sequences available in the gene bank upon BLAST analysis.

Cloning of the partial PFL gene into the TA cloning vector was successful which was evinced by the white colonies obtained in the cloning experiment indicating the successful uptake of recombinant DNA by the competent cells (Fig. 4). Colony PCR resulted in the 609 bp PCR product which indicated the presence of desired gene (partial PFL gene) in the vector (Fig. 5). Isolation of recombinant plasmid by modified alkaline lysis method resulted in good yield and plasmid PCR resulted in the $609 \mathrm{bp}$ PCR product which further confirmed the presence of desired gene (partial PFL gene) in the vector (Fig. 6a and $6 \mathrm{~b})$. The PFL gene sequences of the recombinant plasmid obtained after custom sequencing by Eurofins Genomics India Pvt. Ltd., upon subjecting to BLAST analysis showed 98-99 \% identity with the reference sequences. One of the sequences obtained was submitted to the Genbank (BankIT), NCBI and the sequence was acknowledged with BankIt 2207221-Seq1- MK695632. RE digestion of the recombinant plasmids resulted in the specific bands. When digested with NcoI we obtained two bands corresponding to $3000 \mathrm{~Kb}$ and $1500 \mathrm{~Kb}$ respectively (Sites for NcoI: one in the insert and the other in the Kanamycin resistance ORF) (Fig. 7). Further digestion with Bam HI lead to the release of the cloned insert with overhangs. This insert with overhangs was gel extracted, purified and stored at $-80{ }^{\circ} \mathrm{C}$ for further expression of the protein using PET $32 \mathrm{a}+$ system as stated earlier.

Most of the vaccines in use for $S$. aureus bovine mastitis are given in the parenteral route. But the existence of blood-udder barrier between the systemic circulation and the udder tissue may result in insufficient levels of immune cells and antibodies at the site of infection. Therefore, alternative immunization routes and adjuvant formulations have been suggested in an attempt to increase the local immunity (Coffman et al., 2010; Holmgren et al., 2005; Pulendran et al., 2001). Inducing local antibody production in the udder ancillary to translocation of antibodies from 
serum and parental immunization might (Butler et al., 2015; Boerhout et al., 2015; enhance the antibody levels in the milk Boerhout et al., 2018).

Table.1 Oligonucleotide primers designed for the amplification of Partial PFL gene containing the predicted antigenic site

\begin{tabular}{|c|c|c|c|c|}
\hline Primer & Target gene & Primer sequence $\left(5^{\prime} \rightarrow 3^{\prime}\right)$ & $\begin{array}{l}\text { Restriction } \\
\text { site }\end{array}$ & $\begin{array}{l}\text { Amplicon } \\
\text { size }\end{array}$ \\
\hline $\begin{array}{l}\text { NcoI PFL - } \\
\text { Forward }\end{array}$ & \multirow{2}{*}{$\begin{array}{l}\text { Partial PFL gene } \\
\text { containing the } \\
\text { predicted } \\
\text { antigenic site }\end{array}$} & $\begin{array}{l}\text { GCCCATGGATAATGATGACATT } \\
\text { ATGCGTGAAAG }\end{array}$ & NcoI & \multirow[b]{2}{*}{ 609bp } \\
\hline $\begin{array}{l}\text { BamHI- } \\
\text { PFL -Reverse }\end{array}$ & & $\begin{array}{l}\text { GCGGATCCCATTGTATGTTCTGA } \\
\text { ATCACG }\end{array}$ & BamHI & \\
\hline
\end{tabular}

Fig.1a Schematic representation of the linearized vector, pCR2.1 used for the cloning of partial PFL gene shown below along with the multiple cloning sites (MCS)

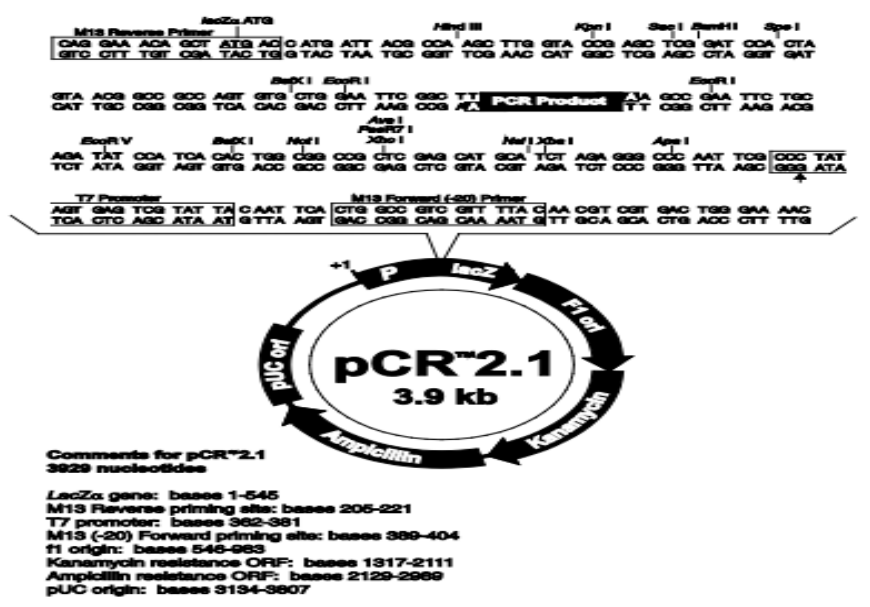

Fig.1b Schematic representation of pET 32a+ vector chosen for the expression of partial PFL gene product

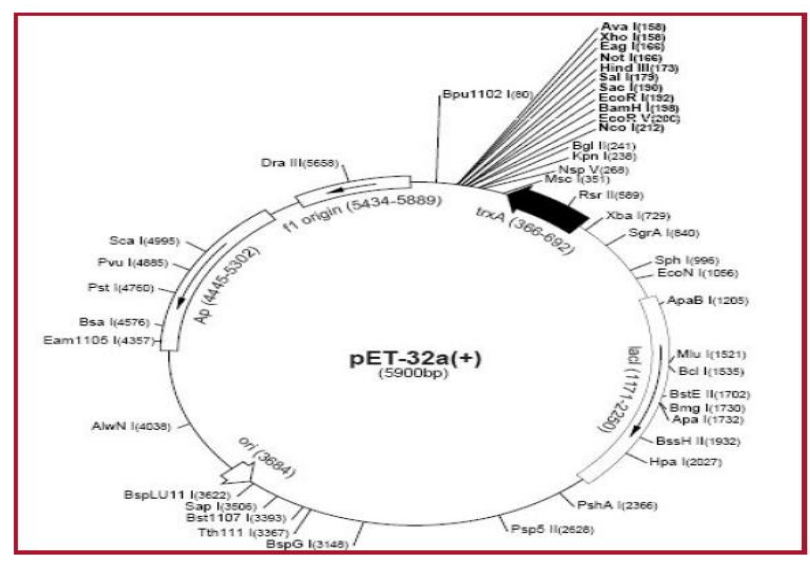


Fig.2 Field strain of $S$. aureus associated with bovine mastitis on Baird parker agar showing black colonies indicating tellurite reduction, surrounded by a clear zone indicating lecithinase production

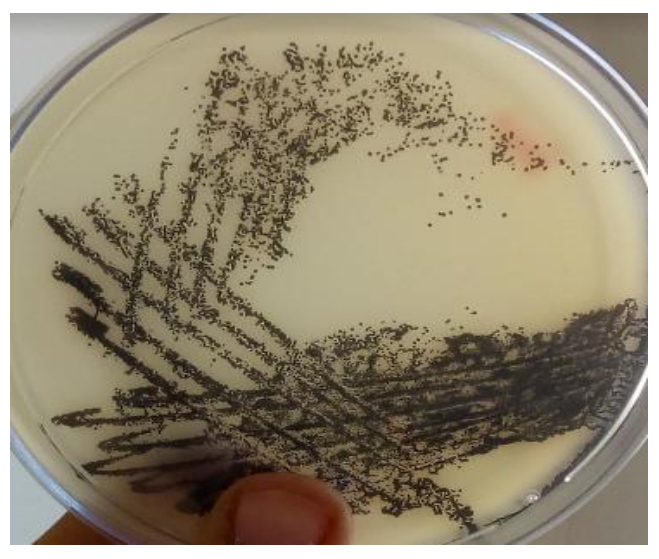

Fig.3 PCR amplification of partial PFL gene of $S$. aureus associated with bovine mastitis with the use of primers designed intended for cloning and expression

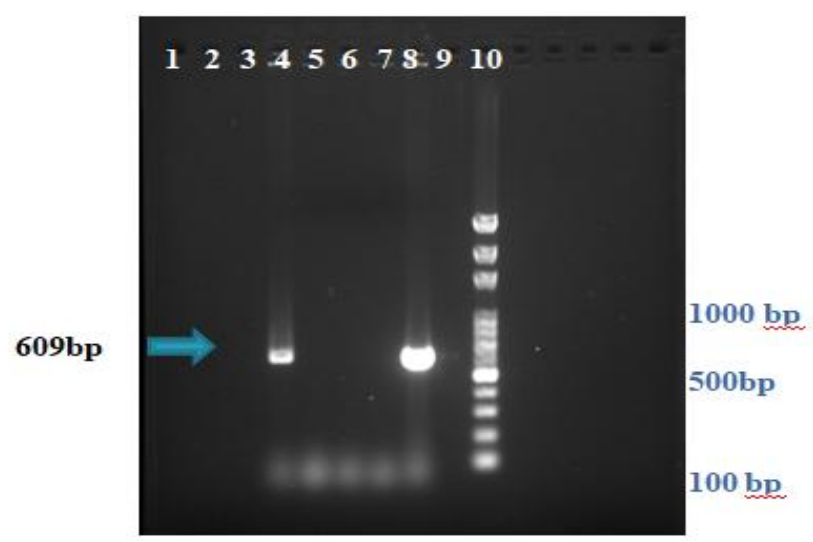

Lanes 4 and 8: Specific amplicons of 609 bp of partial PFL gene of S. aureus; Lane 10: Molecular weight ladder

Fig.4 Transformation of E.coli DH5 $\alpha$ cells with the ligated partial PFL gene of S. aureus

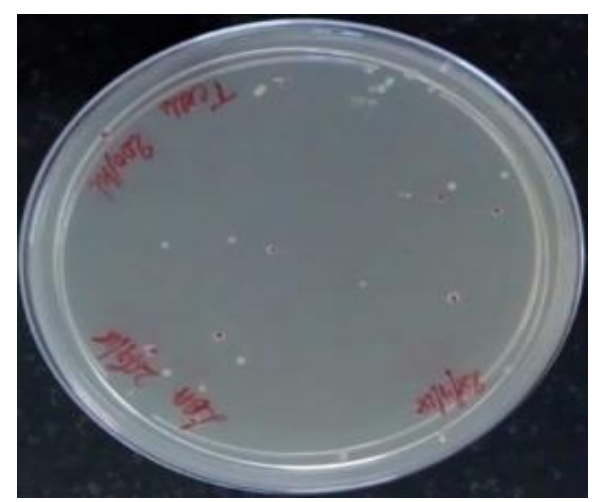

White colonies representative of the recombinant plasmids with the insert are marked on the plate in red for performing colony PCR and plasmid PCR 
Fig.5 Colony PCR amplification of transformed E. coli DH5 $\alpha$ cells with recombinant plasmids

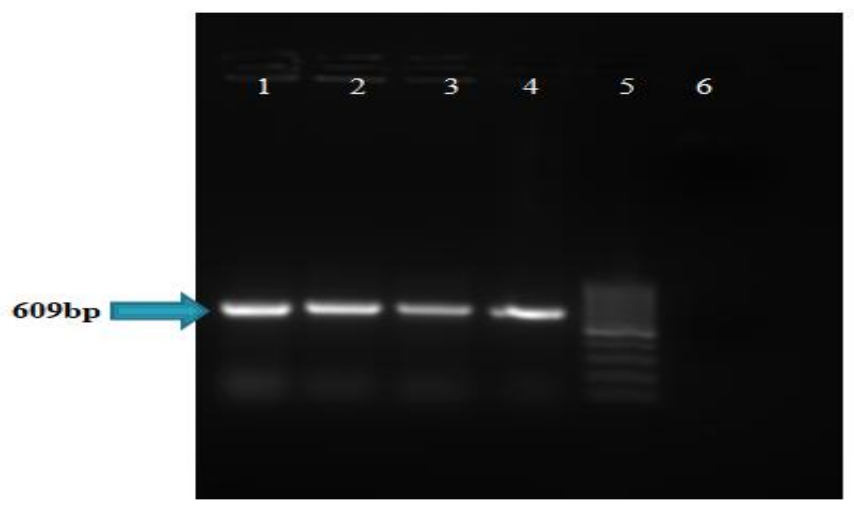

Lanes 1, 2, and 3: white colonies as template; Lane 4: positive control; Lane 5: 100bp DNA ladder; Lane 6: no template control

Fig.6a $\mathrm{r}$ plasmid isolation by modified alkaline lysis method

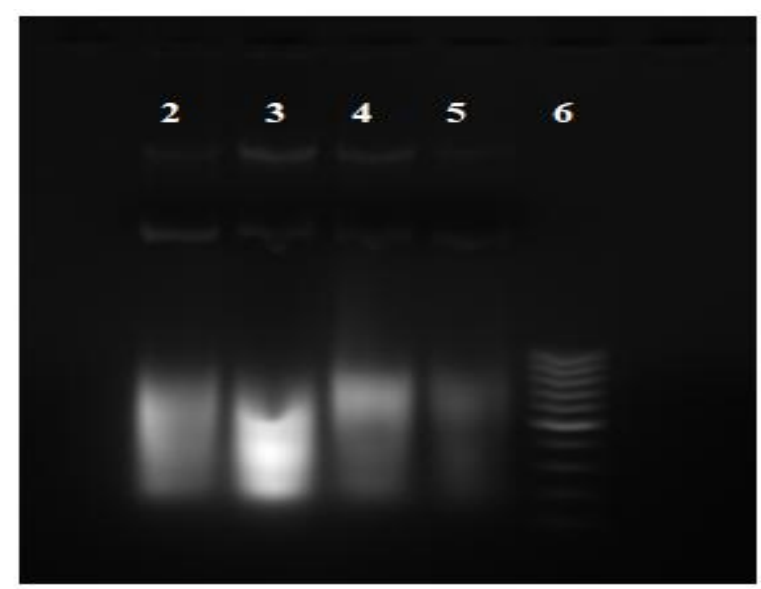

Lanes 2, 3, 4 and 5: Recombinant plasmids isolated by modified alkaline lysis method, Lane 6: 100bp DNA ladder

Fig.6b Plasmid PCR

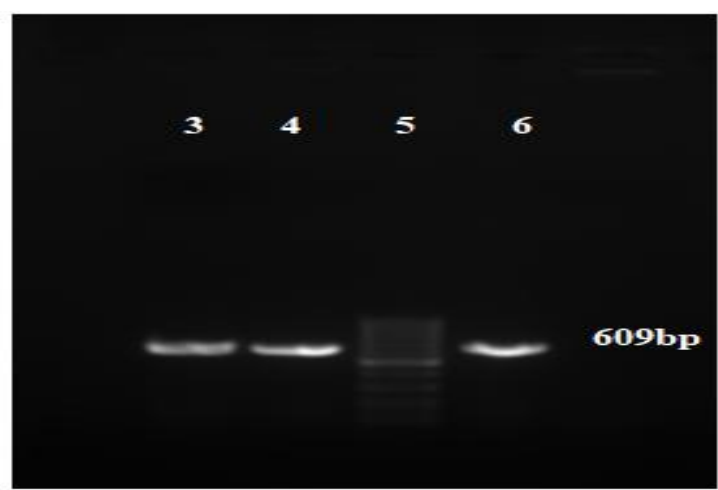

Lanes 3, 4 and 6: 609 bp amplicon of inserted partial PFL gene of $S$. aureus of the recombinant plasmid taken up by the competent cells by transformation 
Fig.7 Restriction enzyme analysis of $\mathrm{r}$ clones

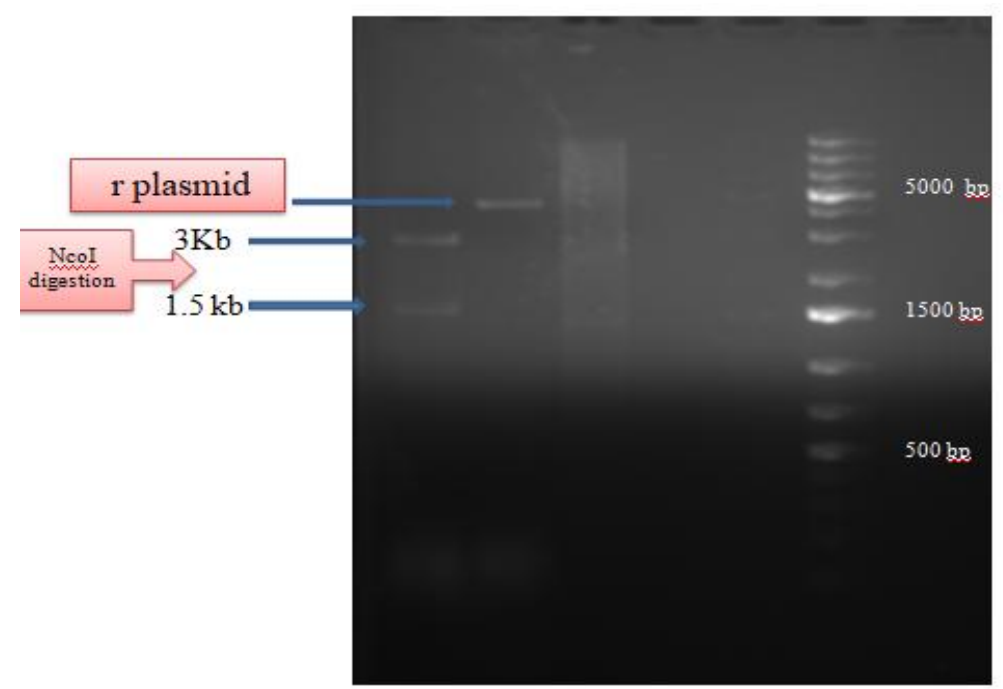

Lanes at the extreme left are showing intact $r$ plasmid and NcoI digested $r$ plasmid products of expected bp size; DNA ladder of known molecular weight has been indicated

As the infections caused by $S$. aureus are multi-drug-resistant, active immunization, the use of novel antibody-based passive immunization strategies might offer a hope in showing enhanced efficacy in the vaccination trails as a part of the development of an effective therapeutic approach (Ansari et al., 2019). Experimental immunization of young heifers with staphylococcal immune evasion molecules, Extracellular fibrinogen-binding protein $(E f b)$, Leukocidin subunit $\mathrm{M}(L u k M)$ resulted in an immune response different from that induced by natural exposure to $S$. aureus, leading to significantly higher antibodies specific for $S$. aureus immune evasion factors locally in the udder (Benedictus et al., 2019). Also, in vitro studies with nano-scale materials such as silver nanoparticles in combination with existing antibiotics have emerged as novel antimicrobial agents to treat infections caused by multi-drug-resistant organisms (Morones et al., 2005; Rai et al 2008; Duran et al., 2010; Ruden et al., 2009; Thirumurugan et al., 2016; Kora and Rastogi., 2013). Autophagy is found to occur in $S$. aureus-infected bovine macrophages but is blocked at a later stage of autophagy. The accumulation of autophagosomes was found to facilitate the survival of $S$. aureus in bovine macrophages (Cai et al., 2020). S. aureus was found to induce autophagy in bovine macrophages, which actually is a cellular homeostatic mechanism in eukaryotes aiding for survival during cellular stress. It is also regarded as a host defence mechanism that contributes to the degradation of intracellular pathogens (Neumann et al., 2016; Wileman 2013). Understanding of the detailed molecular mechanism of how $S$. aureus escape bovine macrophages by autophagic flux to survive in them may provide alternate solutions for targeted therapy.

Recent in vivo research explored to unravel the adaptive mechanisms of $S$. aureus associated with bovine mastitis contributing to chronic, sub-clinical and recurrent udder infections revealed the following interesting findings. S. aureus was found to evolute itself within the udder by exhibiting Sigma factor $B$ $(\operatorname{Sig} B)$ - deficient pathotype characterized by enhanced proteolytic activity and Poly-Nacetylglucosamine (PNAG) based biofilm production, but reduced virulence (Marbach et al., 2019). 
Therefore, the present study is a way forward as one of the alternative attempts to combat $S$. aureus associated bovine mastitis by choosing antigenic site of pyruvate formate lyase as a protein for vaccine preparation, developing an immune assay kit for early diagnosis of subclinical mastitis or for the identification of alternate and effective drugs for the arrest of the growth of the bacteria. Once the purified protein is in hand after expression of partial PFL gene in pET 32a+ vector system, passive immunization with antibodies (produced against this protein) locally in the udder can also be thought of as an alternate option in attempt to enhance the host immune response in the udder or to arrest the growth of the biofilm forming $S$. aureus.

\section{Acknowledgement}

The authors are thankful to Sri Venkateswara Veterinary University, India for providing financial assistance to carry out this research work.

\section{References}

Anitha, T., J. Thanislass, P.X. Antony and B.Sharanabasav. 2014. Detection of Antibodies in Milk for the Pyruvate formate lyase associated with S.aureus isolated from mastitis affected milk by serological proteome analysis. Int.J.Curr.Microbiol.App.Sci. 3(6): 459467.

Annemuller, C., C. Lammler and M. Zschock. 1999. Genotyping of Staphylococcus aureus isolated from bovine mastitis. Vet. Microbiol. 69, 217- 224.

Ansari, S., R.K. Jha, S.K. Mishra, B.R. Tiwari and A.M. Asaad. 2019. Recent advances in Staphylococcus aureus infection: focus on vaccine development. Infect Drug Resist.; 12:1243-1255.

Aslantaş, O., and C. Demir. 2016. Investigation of the antibiotic resistance and biofilmforming ability of Staphylococcus aureus from subclinical bovine mastitis cases. $J$. Dairy Sci. 99:1-7.

Atalla, H., Gyles, C. and Mallard, B. 2011. Staphylococcus aureus small colony variants (SCVs) and their role in disease. Anim. Health Res. Rev. 12, 33-45.

Banerjee, S., A. Kanaujia, R. Yadav and M. J. I. Saxena, 2019. Mastitis Prevalence in Villages of

District Sonipat and Panipat, Haryana. Int.J.Curr.Microbiol.App.Sci. $\quad$ 8(10): 1347-1354

Barrio, M.B., P. Rainard and G. Prevost. 2006. LukM/LukF'-PV is the most active Staphylococcus aureus leukotoxin on bovine neutrophils. Microbes Infec.: 8: 2068-74

Behle, A. 2017. Isolation of plasmid DNA from E. coli (Alkaline lysis method). Institute for Synthetic Microbiology, HeinrichHeine-University.

Benedictus, L., L. Ravesloot, K. Poppe, et al. 2019. Immunization of young heifers with staphylococcal immune evasion proteins before natural exposure to Staphylococcus aureus induces a humoral immune response in serum and milk. BMC Vet Res 15,15

Boerhout, E., M. Vrieling, L. Benedictus , I. Daemen, L. Ravesloot, V. Rutten , P. Nuijten, J. Van Strijp , A. Koets and S. Eisenberg. 2015. Immunization routes in cattle impact the levels and neutralizing capacity of antibodies induced against $S$. aureus immune evasion proteins. Vet Res.; 46: 115.

Boerhout, E.M., A.P. Koets, T.G.T. MolsVorstermans, P.J.M. Nuijten, Hoeijmakers, M.J.H. V.P.M.G. Rutten and J.J.E. Bijlsma. 2018. The antibody response in the bovine mammary gland is influenced by the adjuvant and the site of subcutaneous vaccination. Vet Res.; 49: 25.

Brakstad, O.G., K. Aasbakk and J.A. Maeland. 1992. Detection of Staphylococcus aureus by polymerase chain reaction amplification of the nuc gene, $J$ Clin Microbiol, 30: 1654-1650. 
Butler, J.E., P. Rainard, J. Lippolis, H. Salmon and I. Kacskovics. 2015. Chapter 116 the mammary gland in mucosal and regional immunity A2 - Mestecky, Jiri. In: Strober W, Russell MW, Kelsall BL, Cheroutre H, Lambrecht BN, editors. Mucosal Immunology. 4th ed. Boston: Academic Press; p. 2269-306

Cai, J., L. Jun., Z. Yuqi, J. Wang, J. Li, L. Cui, X. Meng, G. Zhu, H. Wang. 2020. Journal of cellular and molecular medicine. Staphylococcus aureus facilitates its survival in bovine macrophages by blocking autophagic flux. 24(6): 34603468.

Coffman, R.L, A. Sher, and R.A. Seder. 2010. Vaccine adjuvants: putting innate immunity to work. Immunity.; 33: 492503.

Duran, N., P. Marcato, R. De Conti and O. Alves. 2010. Potential use of silver nanoparticles on pathogenic bacteria, their toxicity and possible mechanisms of action. J Braz Chem Soc.; 21: 949.

Falko, H., W. Carmen, S. Fuchs, M. Liebeke, M. Lalk, S. Engelmann and M. Hecker M. 2008. Nitric Oxide Stress Induces Different Responses but Mediates Comparable Protein Thiol Protection in Bacillus subtilis and Staphylococcus aureus, J. Bacteriol, 190: 4997-5008.

Fitzgerald, J.R., W.J. Meaney, P.J. Hartigan, C.J. Smyth and V. Kapur. 1997. Finestructure molecular epidemiological analysis of Staphylococcus aureus recovered cows. Epidemiol. Infect. 119, 261-269.

Gopal, S., and Divya K.C. 2017. Can methicillin-resistant Staphylococcus aureus prevalence from dairy cows in India act as potential risk for communityassociated infections? A review. Vet World. 10(3): 311-318.

Gravel, J. and Malouin, F. 2018. Symposium review: Features of Staphylococcus aureus mastitis pathogenesis that guide vaccine development strategies. Presented as part of the Joint ADSA/ NMC Symposium: Advances in Mammary
Health and Immunology at the ADSA Annual Meeting, Knoxville, Tennessee, American Dairy Science Association

Gresham, H.D., J.H. Lowrance, T.E. Caver, B.S. Wilson, A.L. Cheung and F.P. Lindberg. 2000. Survival of Staphylococcus aureus inside neutrophils contributes to infection. J Immunol. 164: 3713-22.

Gunther, J., W. Petzl., I. Bauer., S. Ponsuksili, H . Zerbe., H-J Schuberth, R.M. Brunner and H-M Seyfert. 2017. Differentiating Staphylococcus aureus from Escherichia coli mastitis: $S$. aureus triggers unbalanced immune-dampening and host cell invasion immediately after udder infection. Sci Rep.; 7: 4811.

Hensen , S.M., M.J. Pavicic., J.A. Lohuis., J.A.D. Hoog and B. Poutrel. 2000. Location of Staphylococcus aureus within the experimentally infected bovine udder and the expression of capsular polysaccharide type 5 in situ. J Dairy Sci. 83: 418-29.

Holmgren, J., and C. Czerkinsky. 2005. Mucosal immunity and vaccines. Nat Med.; 11: S45-53.

Kora, A.J. and L. Rastogi. 2013. Enhancement of antibacterial activity of capped silver nanoparticles in combination with antibiotics, on model gram-negative and gram-positive bacteria. Bioinorg Chem Appl.; $\quad$ 2013: 871097. doi:10.1155/2013/871097

Leibig, M., M. Liebeke, D. Mader, M. Lalk, A. Peschel, F. Gotz. 2011. Pyruvate Formate Lyase Acts as a Formate Supplier for Metabolic Processes during Anaerobiosis in Staphylococcus aureus. Journal of Bacteriology. 193 (4) 952-962

Manasa,V., J.Thanislas and P.X. Antony. 2014. Association of Bio-film formation of $S$. aurues with PFL Gene expression. Int.J.Curr.Microbiol.App.Sci. 3(7) 436448.

Manasa, V., T. Venkata SaiKumar, T. Prasada Rao and K. Aswani Kumar. 2019. Incidence of clinical and sub-clinical bovine mastitis caused by Staphylococcus 
aureus in Proddatur region of Andhra Pradesh. International Journal of Chemical Studies; 7(3): 788-792

Marbach, H., Mayer, K., Vogl, C. et al. 2019. Within-host evolution of bovine Staphylococcus aureus selects for a SigBdeficient pathotype characterized by reduced virulence but enhanced proteolytic activity and biofilm formation. Sci Rep 9, 13479.

Morones, J.R., J.L. Elechiguerra, A. Camacho and J.T. Ramirez. 2005. The bactericidal effect of silver nanoparticles. Nanotechnol.; 16: 2346-2353.

Neumann, Y., Bruns, S.A. Rohde, M. et al. 2016. Intracellular Staphylococcus aureus eludes selective autophagy by activating a host cell kinase. Autophagy. 12: 20692084.

Pulendran, B., J. Banchereau , E. Maraskovsky and C. Maliszewski. 2001. Modulating the immune response with dendritic cells and their growth factors. Trends Immunol.; 22: 41-7.

Rai, M., A. Yadav and A. Gade. 2008. Silver nanoparticles as a new generation of antimicrobials. Biotechnol Adv.; 27:7683.

Rainard, P., G. Foucras, J.R. Fitzgerald., J.L. Watts., G. Koop., and J.R. Middleton. 2018. Knowledge gaps and research priorities in Staphylococcus aureus mastitis control. Transbound Emerg Dis.; 65(Suppl. 1): 149- 165.
Ruden, S., K . Hilpert, M. Berditsch, P. Wadhwani and A. Ulrich. 2009. Synergistic interaction between silver nanoparticles and membranepermeabilizing antimicrobial peptides. Antimicrob Agents Chemother.; 53: 3538.

Saei, H.D., M. Ahmadi, K. Mardani and R.A. Batavani. 2009. Molecular typing of Staphylococcus aureus isolated from bovine mastitis based on polymorphism of the coagulase gene in the north west of Iran. Vet. Microbiol. 137, 202-206.

Tesfaye, G.Y., F.G. Regassa, and B. Kelay. 2010. Milk yield and associated economic losses in quarters with subclinical mastitis due to Staphylococcus aureus in Ethiopian crossbred dairy cows. Tropical Animal Health and Production. 42(5): 925-931.

Thirumurugan, G., S. Rao and M. Dhanaraju. 2016. Elucidating pharmacodynamics interaction of silver nanoparticle-topical deliverable antibiotics. Sci Rep.; 6: 29982.

Wileman, T. 2013. Autophagy as a defence against intracellular pathogens. Essays Biochem. 55: 153-163

Zecconi, A., L. Cesaris., E. Liandris, V. Dapra and R. Piccinini. 2006. Role of several Staphylococcus aureus virulence factors on the inflammatory response in bovine mammary gland. Microb Pathog. 40: 17783.

\section{How to cite this article:}

Varra Manasa, T. Venkata Sai Kumar, T. Prasada Rao, K. Aswani Kumar, J. Thanislass and Girish Kumar, V. 2020. Molecular Cloning of Pyruvate Formate Lyase Gene of Staphylococcus aureus Associated with Bovine Mastitis. Int.J.Curr.Microbiol.App.Sci. 9(12): 476-487. doi: https://doi.org/10.20546/ijcmas.2020.912.058 